VISUAL EXPERIMENT

\title{
Forced swim test in mice: A common animal model of depression
}

\author{
Muhammad Aslam \\ Department of Basic Medical Sciences, Faculty of Pharmacy, Ziauddin University, Karachi 75600, \\ Pakistan. \\ Correspondence: Pharmacologist1@yahoo.com; Cell: +92-3452220192
}

First Published: 16 December, 2015; Updated version: 1.0

DOI: $10.3329 /$ bjp.v11i1.25692

\section{ABSTRACT}

The Forced Swim Test (FST) is a rodent behavioral paradigm utilized for assessment of potential antidepressant-like medications. In this model the mice are put in a plexiglas tank. The tank is loaded with water and the behavior of the mice to escape the tank is scored. The behavioral parameter scored in this test is called immobility, resembling a behavioral state of misery, as seen in human depression.

\section{INTRODUCTION}

The Forced Swim Test (FST) is a rodent behavioral paradigm utilized for assessment of potential antidepressant-like medications. In this model the mice are put in a Plexiglas tank. The tank is loaded with water and the behavior of the mice to escape the tank is scored. The mice try to come out of the water and this behavior is known as "mobility". However, after some time the struggling movements of the mice die down and the mice may surrender and become totally motionless which is known as "immobility". The length of immobility time is scored during the testing period and decrease in the length of time of immobility during this test is termed as antidepressant activity (Liao et al., 2013; Aslam and Sultana, 2015). Fruitful usage of the forced swim test obliges adherence to certain procedural points of interest and minimization of outlandish anxiety to the mice. In this experiment, we are going to give visual details of this important depressive model.

\section{MATERIALS AND EQUIPMENT}

Swimming tank

The equipment used in this test was manufactured using Plexiglas. The dimensions of the cylindrical tank were (diameter $20 \mathrm{~cm}$, height $30 \mathrm{~cm}$ ). The tank was filled with tap water up to $15 \mathrm{~cm}$ height. The temperature of the water was adjusted at $25 \pm 1^{\circ} \mathrm{C}$.

Thermometer

The temperature was adjusted using a glass mercury thermometer.

Stop watch

Stop watch was used to record the mobility time.

Camera to make video clips

Smartphone, iPhone 6, was used to make the video clips.

Tissue rolls:

Every mouse was made dry with tissue roll before returning it to its home cage. 


\section{VIDEO CLIPS}

$\begin{array}{ll}\text { Pre-experiment } & 34 \mathrm{sec} \\ \text { Experiment } & 7 \mathrm{~min} 12 \mathrm{sec}\end{array}$

METHOD

1. Set the camera in the right position

2. Fill the tank to the level of $15 \mathrm{~cm}$ Adjust the water temperature to $25 \pm 1^{\circ} \mathrm{C}$ using hot water and/or ice to adjust the temperature

3. Check the temperature, using a thermometer, before starting the test

4. Bring the mice in laboratory and leave them there for $60 \mathrm{~min}$ for acclimation

5. Gently and slowly pick the mouse by the tail and transfer it into the swimming tank

6. Start the timer already set at $6 \mathrm{~min}(360 \mathrm{sec})$

7. Stop recording at the end of $6 \mathrm{~min}$

8. Remove the mouse from swimming tank. Dry it with tissue before transferring it to its home cage

9. Note down the mobility time for last $4 \mathrm{~min}(240 \mathrm{sec})$ of the aggregate $6 \mathrm{~min}(360 \mathrm{sec})$ test period During initial $2 \mathrm{~min}$ of aggregate $6 \mathrm{~min}$ test period the mouse become exceptionally dynamic, overwhelmingly swim in circles, and attempt to climb the divider or jump to the base

10. Calculate immobility time by subtracting mobility time from the total time

Immobility $=240$ seconds - Mobility

\section{DISCUSSION}

Forced Swimming Test (FST) is one of the most commonly utilized models for assessing potential antidepressant compounds. This model is often used in rodents to evaluate antidepressant-like activity by assessing the decrease in immobility time (Rodrigues et al., 2002; Suzuki et al., 2001). The behavioral parameter scored in this test is called immobility, resembling a behavioral state of misery, as seen in human depression (Steru et al., 1985). In the forced swimming test, mice are constrained to swim in a restricted space from which they can't escape, and are activated to a particular behavior of immobility. This behavior demonstrates a state of despair which can be decreased by antidepressant medications used to treat human depression (Borsini and Meli, 1988; Steru et al., 1985).

\section{REFERENCES}

Aslam M, Sultana N. Vitis vinifera juice ameliorates depression-like behaviourin mice by modulating biogenic amine neurotransmitters. Bangladesh J Pharmacol. 2015; 10: 753-58.

Borsini F, Meli A. Is the forced swimming test a suitable model for revealing antidepressant activity? Psychopharmacol 1988; 94: 147-60.

Liao J, Tsai J, Liu C, Huang H, Wu L, Peng W. Antidepressant-like activity of turmerone in behavioural despair tests in mice. BMC Complement Altern Med. 2013; 13: 299.

Rodrigues A, da Silva G, Mateussi A, Fernandes E, Miguel O, Yunes R, Calixto J, Santos A. Involvement of monoaminergic system in the antidepressant-like effect of the hydroalcoholic extract of Siphocampylus verticillatus. Life Sci. 2002; 70: 1347-58.

Steru L, Chermat R, Thierry B, Simon P. The tail suspension test: A new method for screening antidepressants in mice. Psychopharmacology 1985; 85: 367-70.

Suzuki E, Yagi G, Nakaki T, Kanba S, Asai M. Elevated plasma nitrate levels in depressive states. J Affect Disord. 2001; 63: 221-24. 


\section{Your feedback about this paper}

1. Number of times you have read this paper 0

2. Number of times you have seen the video clip 0

3. Which video clip you may need to see again, if any

4. Quality of paper
O Excellent
O Good
O Moderate
Not good

5. Your comments 